\title{
Citizen Trust and Government Cover-up: Refining the Doctrine of Fraudulent Concealment
}

\author{
Saul B. Shapiro
}

More than a decade after Watergate, neither Congress nor the federal courts have developed law that adequately guards against the government's ability to cover up its wrongdoing and later escape liability by pleading the statute of limitations. To determine when the limitations period begins to run on claims concealed by the government, federal courts employ the tolling standard designed to address relations between parties at arm's length. The government-citizen relationship, however, includes an element of trust and an imbalance of power and access to information that are not present in arm's length dealings. Federal tolling doctrine should be refashioned to reflect that relationship. This Note argues that courts can do this by analyzing cases alleging government cover-up under the tolling standard applied to parties between whom there is a special relationship of trust or confidence.

\section{Fraudulent Concealment and the Government}

\section{A. The Doctrine}

Whenever a party knowingly commits a tort that is self-concealing, or commits a tort and then covers it up, the party is guilty of fraudulent concealment. ${ }^{1}$ A self-concealing tort is one which is inherently unknowable, or which is part of a larger scheme that includes acts designed to

1. Modern fraudulent concealment doctrine is usually traced back to Bailey v. Glover, 88 U.S. (21 Wall.) 342 (1875), and Wood v. Carpenter, 101 U.S. 135 (1879), in which the Supreme Court adopted the doctrine as a matter of federal common law. For a history of how the doctrine has evolved from the common law, see Dawson, Undiscovered Fraud and Statutes of Limitation, 31 MICH. L. Rev. 591 (1933) [hereinafter cited as Dawson, Undiscovered Fraud], and Dawson, Fraudulent Concealment and Statutes of Limitation, 31 MrCH. L. REv. 875 (1933) [hereinafter cited as Dawson, Fraudulent Concealment]. A more recent treatment is available in Marcus, Fraudulent Concealment in Federal Court: Toward a More Disparate Standard?, 71 Geo. L.J. 829 (1983).

At one time the two types of fraudulent concealment were thought of as separate doctrines. Although some courts still make a distinction between self-concealing torts and those that are subsequently concealed, see infra note 39, courts and commentators tend to see both types as comprising the single doctrine of "fraudulent concealment," see, e.g., Hobson v. Wilson, 737 F.2d 1, 33 n.102 (D.C. Cir. 1984), cert. denied sub nom. Brennan v. Hobson, 105 S. Ct. 1843 (1985); Marcus, supra, at 870 . 
prevent the victim from discovering his cause of action. ${ }^{2}$ In such cases, the injury or its cause frequently is not apparent to the victim until after the limitations period has run. ${ }^{3}$ Fraud is the prototypical example, ${ }^{4}$ but a slowly germinating toxic tort ${ }^{5}$ or even a clandestine effort by law enforcement agencies to discredit anti-war activists would also fit into this category. ${ }^{6}$ The second type of concealment occurs when a tort is followed by acts or statements intended to cover up the initial wrongdoing. ${ }^{7}$ In these cases, the injury may be apparent, but the cause of action is concealed. The Army's attempt to cover up the fact that it conducted fatal chemical warfare experimentation on an unwitting patient is an example of this type of concealment. ${ }^{8}$

In these circumstances, a court must decide whether to toll ${ }^{9}$ the statute of limitations. As the Supreme Court explained over a century ago, statutes of limitation:

were enacted to prevent frauds . . . To hold that by concealing a fraud, or by committing a fraud in a manner that it concealed itself until such time as the party committing the fraud could plead the statute of limitations to protect it, is to make the law which was designed to prevent fraud the means by which it is made successful and secure. ${ }^{10}$

2. See Hobson, 737 F.2d at 33-34. In the case of the inherently unknowable tort, some courts hold that the defendant must demonstrate a "minimum of culpability" by, at the least, "construct[ing] a scheme which is by its nature unknowable." Long v. Abbott Mortgage Corp., 459 F. Supp. 108, 118 n.7 (D. Conn. 1978). See generally Marcus, supra note 1, at 865-70 (discussing self-concealing torts); Dawson, Undiscovered Fraud, supra note 1 (same).

3. See, e.g., Nitol v. United States, 7 Cl. Ct. 405, 414 (1985) (injuries from government atomic testing in Marshall Islands became apparent only after limitations had run); Allen v. United States, 588 F. Supp. 247, 341 (D. Utah 1984) (injuries from government atomic testing in Nevada became apparent only after limitations period had run).

4. Indeed, at one time the commission of a self-concealing tort was classified as fraudulent concealment only if the concealed cause of action itself was premised on fraud. This approach has been abandoned. See Marcus, supra note 1, at 867-69.

5. See, e.g., cases cited supra note 3.

6. Hobson v. Wilson, 737 F.2d 1, 36-37 (D.C. Cir. 1984) (federal and local law enforcement agencies engaged in campaign of wiretapping and disinformation to undermine civil rights and antiwar groups), cert. denied sub nom. Brennan v. Hobson, 105 S. Ct. 1843 (1985).

7. See, e.g., Hohri v. United States, 782 F.2d 227, 248 (D.C. Cir. 1986) (government covered up knowledge that there was no military necessity for West Coast concentration camps during World War II). See generally Hobson, 737 F.2d at 33-34 (discussing affirmative concealment); Dawson, Fraudulent Concealment, supra note 1, at 877-82 (same).

8. See Barrett v. United States, 689 F.2d 324 (2d Cir. 1982), cert. denied sub nom. Cattell v. Barrett, 462 U.S. 1131 (1983).

9. "To suspend or stop temporarily." BLACk's LAw Dictionary 1334 (5th ed. 1979).

10. Bailey v. Glover, 88 U.S. (21 Wall.) 342, 349 (1875). As a more recent court explained fraudulent concealment:

In such cases, the underlying policy of the statute of limitations, discouraging litigation of "stale" claims, does not arise. The claim is not stale. It merely took time to accrue. Genuine concern about lost evidence, fading memories and the passage of time are subordinated to a greater concern that legal wrongs be remedied at the first practical opportunity.

Allen v. United States, 588 F. Supp. 247, 341 (D. Utah 1984). 


\section{Government Cover-up}

The common law developed two standards for tolling the statute of limitations in cases of fraudulent concealment. ${ }^{11}$ One standard is applied to parties at arm's length, ${ }^{12}$ the other to parties between whom there is a relationship of trust or confidence. ${ }^{13}$ Under both standards the defendant's concealment of material information surrounding his wrongdoing tolls the limitations period until plaintiff discovers, or in the exercise of due diligence should have discovered, the concealed cause of action. ${ }^{14}$ Within that common framework, however, the two standards are very different. The arm's length standard takes a much more expansive view of what should place a plaintiff on notice of his claim, and a much narrower view of what constitutes concealment. For the plaintiff seeking to toll the limitations period, the decision of which standard is applied can determine whether or not he is able to bring his substantive claim in court.

Under the arm's length standard, the diligence of the plaintiff's inquiry into the existence of a claim is judged according to an objective reasonable person standard. No allowance is made for any trust plaintiff may have had in the honesty of defendant's behavior or representations. ${ }^{15}$ More important, the arm's length rules define concealment very narrowly: The defendant is under no duty to disclose her wrongdoing. Her silence will not stop the clock from running on an injured plaintiff's cause of action. ${ }^{16}$ Indeed, the defendant's denial of wrongdoing does not constitute fraudulent concealment, and will not serve to toll the statute of limitations. ${ }^{17}$

Courts find the arm's length standard too harsh to apply to certain relationships. In relationships where the concealing party's honesty or forthrightness is expected or should be encouraged, courts apply a different standard. ${ }^{18}$ Under this "trusted defendant" stan39.

11. The Seventh and Second Circuits apply a slight modification of these standards. See infra note

12. See infra notes $15-16$ and accompanying text.

13. See infra notes $18-22$ and accompanying text.

14. See, e.g., Ramsey v. Culpepper, 738 F.2d 1092, 1098 \& n.2 (10th Cir. 1984) (applying trusted defendant standard); Fitzgerald v. Seamans, 553 F.2d 220, 228 (D.C. Cir. 1977) (applying arm's length standard).

15. See, e.g., Campbell v. Upjohn Co., 498 F. Supp. 722, 727-28 (W.D. Mich. 1980), affd, 676 F.2d 1122 (6th Cir. 1982); Long v. Abbott Mortgage Corp., 459 F. Supp. 108, 117 n.5 (D. Conn. 1978). See generally Marcus, supra note 1 , at 878-82 (discussing objective standard).

16. See Wood v. Carpenter, 101 U.S. 135, 143 (1879); Rutledge v. Boston Woven Hose \& Rubber Co., 576 F.2d 248, 250 (9th Cir. 1978); Dayco Corp. v. Firestone Tire \& Rubber Co., 386 F. Supp. 546, 549 (N.D. Ohio 1974), affd, 523 F.2d 389 (6th Cir. 1975). See generally Marcus, supra note 1, at 864-65 (discussing rules governing concealment).

17. See, e.g., Davis v. United States, 642 F.2d 328, 332 (9th Cir. 1981), cert. denied, 455 U.S. 919 (1982); Peck v. United States, 470 F. Supp. 1003, 1019 (S.D.N.Y. 1979); Dayco, 386 F. Supp. at 549. But see Rutledge, 576 F. Supp. at 250 (stating in dictum that denial "may" in certain circumstances constitute concealment). See generally Marcus, supra note 1, at 861-64 (discussing denial).

18. See Dawson, Fraudulent Concealment, supra note 1, at 879 \& $\mathrm{n.11}$ (citing cases); Dawson, Undiscovered Fraud, supra note 1, at 610-14. For a more elaborate discussion of the relationships which have warranted the different standard, see infra note 22. 
dard, ${ }^{19}$ the concealing party is under a duty to disclose his wrongdoing to the plaintiff. His failure to disclose, or his denial of wrongdoing, constitutes fraudulent concealment, tolling the statute of limitations. ${ }^{20}$ As under the arm's length standard, the limitations period remains tolled until the injured party discovers, or in the court's judgment should have discovered, the concealed cause of action. But in determining when the plaintiff should have discovered the concealed cause of action, the existence of the relationship of trust reduces the degree of diligence required of the plaintiff. The plaintiff has no duty to mistrust the statements of the trusted defendant, and may rely on him to disclose all facts material to any wrongdoing. Thus, the plaintiff is excused from investigating facts that, in an arm's length relationship, would put him on notice of possible wrongdoing. ${ }^{21}$

The relationships that have been found to warrant the trusted defendant standard cannot easily be categorized. While the standard applies to fiduciary relationships, it also applies to a wide range of relationships that do not meet that strict legal standard. ${ }^{22}$ Because the labels courts have

19. There is no formal term for this standard. The relationships that give rise to the standard have been given many labels. See infra note 22. The term "trusted defendant" seems most descriptive of the full panoply of relationships to which the standard has been applied.

20. See, e.g., Ramsey v. Culpepper, 738 F.2d 1092, 1098 n.2 (10th Cir. 1984); Canton Lutheran Church v. Sovik, Mathre, Sathrum \& Quanbeck, 507 F. Supp. 873, 878 (D.S.D. 1981); see also Rutledge, 576 F.2d at 250 (discussing trusted defendant standard). See generally Developments in the Law-Statutes of Limitations, 63 HARV. L. REV. 1177, 1221 (1950) [hereinafter cited as Developments] (same).

21. See, e.g., Ramsey, 738 F.2d at 1098 n.2; Bennett v. Hibernia Bank, 47 Cal. 2d 540, 550, 305 P.2d 20, 33 (1957).

Application of the trusted defendant standard does not, however, relieve plaintiff of his duty to make a reasonable investigation; it only affects what the court considers reasonable. See, e.g., Hupp v. Gray, 500 F.2d 993, 997 (7th Cir. 1974) (limitations period had run on plaintiffs claim despite "fiduciary relationship"); see also Gee v. CBS, Inc., 471 F. Supp. 600, 630 (E.D. Pa.) ("the phrase 'breach of fiduciary duty' is not talismanic, in the presence of which the statute of limitations withers away"), affd, 612 F.2d 572 (3d Cir. 1979).

22. See Dawson, Fraudulent Concealment, supra note 1, at 879 n.11 (citing cases "where the plaintiff's reliance was justified, not by the 'fiduciary' character of the defendant's obligation inferred as a matter of law, but by an expectation of good faith known to the other party and abused"); Ramsey, 738 F.2d at 1096 (tolling limitations period in light of "confidential" relationship between elderly absentee landlord and local real estate broker); Spinelli, Kehiayan-Berkman, S.A. v. Imas Gruner, A.I.A. \& Assoc., 602 F. Supp. 372, 375 (D. Md. 1985) (tolling limitations period in light of "fiduciary" relationship between managing partners and limited partners); Canton Lutheran Church v. Sovik, Mathre, Sathrum \& Quanbeck, 507 F. Supp. 873, 878 (D.S.D. 1981) (tolling limitations period in light of relationship of "trust and confidence" between architect and client); Developments, supra note 20, at 1221 (relationships "of a fiduciary nature" warrant trusted defendant standard).

Perhaps the best exegesis of the relationships to which the trusted defendant standard has been applied is contained in the Restatement's definition of confidential relations:

A confidential relation exists between two persons when one has gained the confidence of the other and purports to act with the other's interest in mind. A confidential relation may exist although there is no fiduciary relation; it is particularly likely to exist where there is a family relationship or one of friendship ....

1 Restatement (Second) of Trusts $\$ 2$ (b) (1959). 
used to describe relationships warranting the standard are not exact ${ }^{23}$ and often appear to be attached without sufficient care, ${ }^{24}$ an understanding of which relationships warrant the trusted defendant standard is better gleaned from an analysis of the factors courts have considered relevant than from the labels they have attached. In general, courts apply the standard to relationships in which there is trust or confidence between the parties, ${ }^{28}$ where there is an inequality of power between the parties, ${ }^{26}$ or where the concealing party has vastly superior access to information concerning the concealed cause of action. ${ }^{27}$ Courts have taken note of particular categories of relationships that are expected to give rise to a duty of honesty and forthrightness. ${ }^{28}$ Those categories, however, while extremely relevant to the courts' decisions, have not been dispositive. Instead, courts usually decide which tolling standard to apply on the basis of the sum of relations between the parties. ${ }^{28}$

23. See 15A C.J.S. Confidential (1955) 355 (confidential relationships "impossible of exact or precise definition"); Coffee, From Tort to Crime: Some Reflections on the Criminalization of Fiduciary Breaches and the Problematic Line Between Law and Ethics, 19 AM. CRIM. L. REv. 117, 154-56 (1981) (definition of fiduciary duty varies from state to state).

24. See 1 Restatement (SECOND) of TRUSTs $\$ 4$ (1959) ("the term 'trust' is sometimes used loosely" giving rise to unjustified range of duties); Coffee, supra note 23, at 141 ("the term 'fiduciary" can become a substitute for close analysis, a rhetorical flourish to be used in place of a logical distinction"); see also United States v. Margiotta, 688 F.2d 108, 142 (2d Cir. 1982) (Winter, J., dissenting) ("It)he words fiduciary duty are no more than a legal conclusion and the legal obligations actually imposed under that label vary greatly from relationship to relationship"), cert. denied, 461 U.S. 913 (1983).

25. See, e.g., Ramsey, 738 F.2d at 1097 (tolling statute of limitations in light of elderly absentee landlord's trust in local real estate broker); State Farm Mut. Auto. Ins. Co. v. Ling, 348 So. 2d 472, 475 (Ala. 1977) (because adversary insurance company had gained plaintiff's confidence, its failure to tell him that limitations might run on his claim tolled the limitations period). See generally Dawson, Fraudulent Concealment, supra note 1, at 879 n.11 (citing cases).

26. See, e.g., Ramsey, 738 F.2d at 1096 (plaintiff's dependence on defendant is factor in tolling standard); Baselski v. Paine, Webber, Jackson \& Curtis, Inc, 514 F. Supp. 535, 540 (N.D. Ill. 1981) (tolling limitations based on plaintiff's relative "unsophistication"). See generally Dawson, Fraudulent Concealment, supra note 1, at 879 ("personal inequality" is factor warranting change in tolling standard).

27. See, e.g., Ramsey, 738 F.2d at 1097 (tolling limitations in part because defendant was plaintiffs only source of information about events surrounding wrongdoing); State Farm Mut. Auto. Ins. Co. v. Ling, 348 So. 2d 472, 475 (Ala. 1977) (limitations tolled in part because of defendant's "special and superior knowledge").

28. See, e.g., Spinelli, Kehiayan-Berkman, S.A. v. Imas Gruner, A.I.A. \& Assoc, 602 F. Supp. 372, 375 (D. Md. 1985) (managing partners and general partners); Bazelshi, 514 F. Supp. at 540 (investor and securities firm).

29. When the formal relationship between the parties suggests that the trusted defendant standard is applicable, but the facts indicate otherwise, the court will apply the arm's length standard. See, e.g., Tonsmeire v. Tonsmeire, 285 Ala. 454, 456, 233 So. 2d 465, 467 (Ala. 1970) (arm's length standard applied in libel suit brought by wife against husband where "trust and affection has vanished from their relationship"). 


\section{B. Government Concealment Under the Arm's Length Standard}

Federal courts ${ }^{30}$ analyze government ${ }^{31}$ cover-up under the arm's length standard..$^{32}$ The arm's length standard's limitations on what constitutes concealment does not account for any faith the plaintiff may place in the honesty of government statements or conduct. Under the arm's length standard, the government has no duty to inform citizens of the injuries it

30. This discussion will focus on federal fraudulent concealment doctrine. Since the Supreme Court's 1946 holding that federal fraudulent concealment doctrine is read into "every" federal cause of action, Holmberg v. Armbrecht, 327 U.S. 392, 397 (1946), federal courts have applied federal fraudulent concealment doctrine to adopted state statutes of limitation as well as to federal statutes of limitation. See generally Marcus, supra note 1, at 831-33, 839-41 (discussing emergence and extent of federal fraudulent concealment doctrine). Federal fraudulent concealment doctrine thus applies to tort suits based on federal causes of action against federal, state and local government and government officials. This includes suits where a federal limitations period is prescribed in the statute, for example, under the Federal Tort Claims Act (FTCA), 28 U.S.C. $\$ 1346(b), 2671-80$ (1982) (which contains a limitations period at 28 U.S.C. § 2401(b) (1982)), e.g., Barrett v. United States, 689 F.2d 324, 327 (2d Cir. 1982), cert. denied sub nom. Cattell v. Barrett, 462 U.S. 1131 (1983), and under the Tucker Act, 28 U.S.C. $\$ 1346(a)(2)$ (1982) (which includes a limitations period at 28 U.S.C. 2401(a) (1982)), e.g., Hohri v. United States, 782 F.2d 227, 246 (D.C. Cir. 1986). In addition, this discussion will assume that federal courts will continue to apply federal fraudulent concealment doctrine to adopted state statutes of limitation. Some uncertainty concerning the source of tolling doctrine was created by Johnson v. Railway Express Agency, Inc., 421 U.S. 454 (1975), and Board of Regents v. Tomanio, 446 U.S. 478 (1980), which together can be read broadly to require federal courts to apply state tolling doctrine when adopting state statutes of limitation. Nevertheless, federal courts continue to apply federal fraudulent concealment doctrine to adopted state statutes of limitation. See, e.g., Sevier v. Turner, 742 F.2d 262, 272 (6th Cir. 1984) (applying federal doctrine to adopted state statute of limitations in suit under 42 U.S.C. $\$ 1983$ (1982)); Richards v. Mileski, 662 F.2d 65, 68 (D.C. Cir. 1981) (applying federal doctrine to suit directly under the Constitution); see also Marcus, supra note 1 , at $845-55$ (federal courts should continue to apply federal doctrine). But see Vest v. Bossard, 700 F.2d 600, 602-04 (10th Cir. 1983) (applying state law to suit under § 1983).

With respect to any uncertainty over the source of tolling doctrine, it should be noted that the argument presented here is as applicable to state tolling doctrine as to federal law. Indeed, because federal doctrine is generally more liberal than state doctrine, see Marcus, supra note 1, at 834-35 n. 41 , if federal courts began to apply state law to adopted state statutes of limitation there would be an even more compelling need for the application of the trusted defendant standard to government concealment.

31. "Government" will refer to federal, state and local governments and government officials. Fraudulently concealed federal actions against these parties may be tolled according to traditional tolling principles under the Supreme Court's holding in Holmberg, 327 U.S. at 397, that federal fraudulent concealment tolling doctrine is read into "every" federal cause of action (without regard to the identity of the parties). See Hohri v. United States, 782 F.2d 227, 247 (D.C. Cir. 1986) (discussing Holmberg); see also supra note 30 (citing cases tolling actions against government).

On two occasions, courts have held that because statutes of limitations governing suits against the United States are limited waivers of the government's sovereign immunity to which exceptions are to be strictly construed, fraudulent concealment does not apply. See Hammond v. United States, 388 F. Supp. 928, 934 (E.D.N.Y. 1975); Richter v. United States, 551 F.2d 1177, 1177 (9th Cir. 1977) (following Hammond without explanation). Both decisions have been superceded. See Gibson v. United States, 781 F.2d 1334, 1344-45 (9th Cir. 1986) (superceding Richter); Barrett, 689 F.2d at 330 (superceding Hammond). As Hohri pointed out, courts adopted the doctrine of fraudulent concealment long before the middle of the nineteenth century. To hold that the doctrine was not incorporated into any subsequently enacted federal statute of limitations would do violence to congressional intent. Hohri, 782 F.2d at 247-48.

32. See, e.g., Hobson v. Wilson, 737 F.2d 1, 33-36 (D.C. Cir. 1984), cert. denied sub nom. Brennan v. Hobson, 105 S. Ct. 1843 (1985); Davis v. United States, 642 F.2d 328, 332 (9th Cir. 1981), cert. denied, 455 U.S. 919 (1982); Peck v. United States, 470 F. Supp. 1003, 1019 (S.D.N.Y. 1979). 


\section{Government Cover-up}

has caused them. ${ }^{33}$ It may remain silent while the limitations period runs on their claims. ${ }^{34}$ The limitations period will not be tolled if the government denies responsibility-even if it knowingly lies-in response to a citizen's request for information about his injury. ${ }^{35}$ Indeed, one court held that the government's denial of wrongdoing should have aroused plaintiff's suspicion and put him on notice of his claim..$^{36}$

Similarly, the arm's length standard's objective due diligence test does not make allowances for a citizen's trust in government. ${ }^{37}$ Without regard to whether government concealment might have posed a special bar to particular plaintiffs, courts have held that plaintiffs failed to exercise sufficient diligence in pursuit of their claims. ${ }^{38}$ Despite the fact that many of these decisions are often based on no more than speculation about what should have put a plaintiff on notice of her claim, ${ }^{39}$ some plaintiffs have

33. See Davis v. United States, 642 F.2d 328, 332 (9th Gir. 1981) ("It may well be that the government was negligent in maintaining and publishing records. However, failure of the government to ascertain and publish the fact of its negligence is hardly sufficient to constitute fraudulent concealment."), cert. denied, 455 U.S. 919 (1982); Hauptmann v. Wilentz, 570 F. Supp. 351, 399 (D.N.J. 1983), affd, 770 F.2d 1070 (3d Cir. 1985); Peck v. United States, 470 F. Supp. 1003, 1019 (S.D.N.Y. 1979) ("As to the failure to disclose the government's role in the Freedom Ride in the 1961 action, the law is clear that, in the absence of a fiduciary duty between the parties, mere failure to disclose the existence of a cause of action does not constitute concealment.").

34. See Hernandez Jimenez v. Colero Toledo, 604 F.2d 99, 101-02 (1st Cir. 1979); Hauptmann, 570 F. Supp. at 399; Peck, 470 F. Supp. at 1019.

35. See Davis, 642 F.2d at 332; Hauptmann, 570 F. Supp. at 399; Peck, 470 F. Supp. at 1019; see also Welcker v. United States, 752 F.2d 1577, 1583 (Fed. Cir.) (rejecting argument that government employee's suit to recover for wrongful dismissal in 1950's loyalty security proceeding was tolled by belief that judicial protest would have been futile in the face of government denial and "the tenor of the times"), cert. denied, $106 \mathrm{~S}$. Ct. 83 (1985).

36. Davis, 642 F.2d at 332 n.10 (government press release and reports denying connection between government polio vaccine and contraction of polio should have helped to put polio victim on notice of his claim).

37. See Richards v. Mileski, 662 F.2d 65, 71 (D.C. Cir. 1981) (applying reasonable person standard in suit alleging government concealment).

38. For example, in Hernandez Jimenez v. Colero Toledo, 604 F.2d 99 (1st Cir. 1979), the court held that plaintiff, a government official fired for political reasons, did not make a diligent search into the circumstances surrounding his dismissal. The court did not consider that evidence of the political conspiracy might have been difficult to uncover. The court even went so far as to suggest that the fact that plaintiff's friend eventually learned of the conspiracy by overhearing a discussion at a celebration in a village square was evidence of how easily the information could have been obtained. Id. at 102 . See also Sevier v. Turner, 742 F.2d 262, 273 (6th Cir. 1984) (limitations had run on civil rights action against law enforcement officers because plaintiff should have known his legal rights were being violated and that he had a right to counsel).

39. It is hard to summarize due diligence decisions. While plaintiffs have been held to have been put on notice of their claims by newspaper articles they did not necessarily read, see cases cited infra note 41 , other courts have found that plaintiffs may not have been put on notice by massive and relatively undisguised torts. Pollard v. United States, 384 F. Supp 304, 307-08 (M.D. Ala. 1974) (rejecting government's motion for summary judgment in suit brought by plaintiff class of former participants in 1940's syphilis study). Circuit courts have simply disagreed with the court below over whether the concealed information was necessary to put the plaintiff on notice of his claim, compare Fitzgerald v. Seamans, 384 F. Supp. 688, 694 (D.D.C. 1974) with Fitzgerald, 553 F.2d 220, 229 (D.C. Cir. 1977); or whether the plaintiff should have been more diligent, compare Hohri v. United States, 586 F. Supp. 769, 791 (D.D.C. 1984) with Hohri, 782 F.2d 227, 251-55 (D.C. Cir. 1986).

The presence of the government as the defendant only exacerbates a general difficulty the courts 
been barred on the basis of the limited facts available at the pleading stage. ${ }^{40}$ One court dismissed a claim alleging constitutional injuries because of its belief that constructive notice was created by reporting in the "nation's leading newspapers." 4 Where courts have held that plaintiffs are put on notice of their claims by the mere awareness of their injury-rather than when they know of a particular cause of action against particular defendants ${ }^{42}$-the difficulties facing plaintiffs under the arm's length standard are exacerbated. ${ }^{43}$

have experienced applying the objective due diligence test. See generally Marcus, supra note 1, at 899 (courts" "eclectic approach" has made it "impossible to reconcile all the cases"). As a result of this difficulty and to avoid allowing a defendant to escape solely as a result of the plaintiff's naivete or laxity, two circuits and one district court in another circuit toll the limitations until the plaintiffs actual discovery of the cause of action when torts have been affirmatively concealed. See Tomera v. Galt, 511 F.2d 504, 510 (7th Cir. 1975); Robertson v. Seidman \& Seidman, 609 F.2d 583, 593 (2d Cir. 1979); McConnell v. Frank Howard Allen \& Co., 574 F. Supp. 781, 788 (N.D. Cal. 1983). This change in the doctrine has not been followed widely. See, e.g., Cambell v. Upjohn, 676 F.2d 1122, 1127 (6th Cir. 1982) (actual discovery standard "would have the statute tolled indefinitely, while evidence stales, memories fade and courts and adversaries wait, until the plaintiff at his leisure alleges actual discovery"); see also Hohri, 782 F.2d at 248 \& n.54 (following Campbell, but noting that split may be "more apparent than real" because active concealment cases have involved such effective concealment that no plaintiff could be expected to uncover wrongdoing).

40. See, e.g., Lee v. Kelley, No. 76-1185, slip op. (D.D.C. Jan. 31, 1977) (on motion to dismiss rejecting plaintiff's argument that government concealment tolled the limitations period); see also Richards v. Mileski, 662 F.2d 65, 73 (D.C. Cir. 1981) (reversing district court that granted government's motion to dismiss without even hearing oral argument on the issue of concealment); Smith v. Nixon, 606 F.2d 1183, 1186 (D.C. Cir. 1979) (reversing district court's dismissal of plaintiffs allegation of government concealment on motion to dismiss), cert. denied, 453 U.S. 912 (1981). As the Richards court noted:

There is an inherent problem in using a motion to dismiss for purposes of raising a statute of

limitations defense. Although it is true that a complaint sometimes discloses such defects on its

face, it is more likely that the plaintiff can raise factual setoffs to such an affirmative defense.

662 F.2d at 73. See generally Marcus, supra note 1, at 904 (arguing that courts should cease practice of dismissing claims alleging fraudulent concealment on pleadings).

41. Lee, slip op. at 3 (civil rights action filed by former assistant to Dr. Martin Luther King accrued not when illegal wiretapping was revealed in 1975 Senate report but in 1960's when the "nation's leading newspapers were rife with accounts of buggings of Dr. King"); see also United Klans of America v. McGovern, 621 F.2d 152, 154 (5th Cir. 1980) (plaintiffs put on notice by press reporting). But see Hobson v. Wilson, 737 F.2d 1, 39 n.118 (D.C. Cir. 1984) (plaintiffs claim remains alive if he did not read newspaper article that would have put him on notice), cert. denied sub nom. Brennan v. Hobson, 105 S. Ct. 1843 (1985).

42. See Hobson, 737 F.2d at 35, 36 (discussing standard and citing cases).

43. For example, in Gibson v. United States, 781 F.2d 1334 (9th Cir. 1986), the court barred a Federal Tort Claims Act claim alleging that, as part of an effort to hinder plaintiff's political activities, FBI agents directed an agent provocateur to steal documents from plaintiff's garage and set the garage on fire to cover his tracks. Plaintiff also alleged that the FBI further concealed its actions by filing a fictitious account of the incident with the local fire department, blaming the fire on a negligent marijuana-smoking teenager. Id. at 1343. The court rejected plaintiff's argument that the limitations period should have been tolled until she discovered the government's role in the wrongdoing. Rather than treating the entire scheme as a self-concealing tort, see supra text accompanying notes 2-6, or the fire and the phone call to the fire department as affirmative acts of concealment following the original tort, see supra text accompanying notes $7-8$, and tolling the limitations period until plaintiff could bring a claim against particular defendants, the court treated the call as the only act of concealment. Id. at 1345. The court analyzed the fire under a medical malpractice accrual standard, holding that the limitations period began to run almost immediately after the blaze was discovered; i.e., at the point that plaintiff knew the fact of her injury (the lost garage) and its cause (the fire). Id. at 1344. In 


\section{Government Gover-up}

Application of the arm's length standard to government-citizen relationships has been damaging as much for the confusion it has created as for the injustices it has wrought. Faced with egregious acts of government cover-up, federal courts, particularly at the circuit level, have found a variety of ways to keep suits alive. A few courts have gone outside the parameters of equitable tolling doctrine in attempts to take account of the government-citizen relationship. ${ }^{44}$ More often, however, courts have applied aspects of the trusted defendant standard under the rubric of the arm's length doctrine. Thus, courts have reduced the diligence required of plaintiffs alleging government cover-up. ${ }^{45}$ In addition, one court expanded its definition of concealment to include denial,,$^{46}$ and at least two courts have come close to imposing on government a duty of disclosure.

In Allen v. United States, ${ }^{47}$ a suit to recover damages for cancer and leukemia allegedly caused by atomic testing in Nevada, the court noted that the "clock of limitations could have started to run a long time ago had the [government] but started it by imparting to the population at risk that which it then knew or had reason-and real opportunity-to know and which the plaintiffs are just now finding out." ${ }^{\text {"48 }}$ Similarly, in Hohri $v$.

its fraudulent concealment analysis, the court held that the fictitious report the FBI filed with the fire department did not constitute concealment because evidence available immediately after the fire was discovered suggested arson. Id. at 1345. For a discussion distinguishing accrual under medical malpractice from tolling under fraudulent concealment, see Hohri v. United States, 782 F.2d 227, 249 n.56 (D.C. Cir. 1986).

44. See Bell v. Milwaukee, 746 F.2d 1205, 1229-31 (7th Cir. 1984) (employing Wisconsin equitable estoppel doctrine to ensure a remedy for plaintiffs seeking redress for gross civil rights violations by police officers); Saffron v. Wilson, 481 F. Supp. 228, 255 (D.D.C. 1979) (altering pleading and discovery requirements for plaintiff alleging fraudulent concealment by the Secret Service). For a discussion of why equitable estoppel is not an adequate substitute for the arm's length standard, see infra note 105 and accompanying text.

45. See Liuzzo v. United States, 485 F. Supp. 1274, 1284 (E.D. Mich. 1980) ("activity that tends to hide the participation of government related personnel in torts that occur in the course of their duties may provide a longer time to those injured to make claims than would be true if other methods were used").

46. See Smith v. Nixon, 606 F.2d 1183, 1191 n. 44 (D.C. Cir. 1979), cert. denied, 453 U.S. 912 (1981) (defendant government officials' incorrect denial of allegations of wrongdoing made in press and failure to inform Department of Justice of wiretap records that were relevant to related criminal prosecution constituted fraudulent concealment). The basis of the Smith holding is unclear. First, it is unclear whether the denial itself was sufficient to constitute concealment. Assuming that it was, the court's reasoning remains a mystery. The court specifically rejected the possibility that fiduciary relations existed between the parties, id. at 1190, yet purported to follow "traditional" tolling doctrine. Id. at 1191 n.44. The court's reasoning, however, is hardly traditional: The court drew an analogy between the government's conduct in the case before it, and the cloak of secrecy that surrounded the government's wrongdoing in Fitzgerald v. Seamans, 553 F.2d 220 (D.C. Cir. 1977). In Fitzgerald, the court had held that the secretive nature of a tortious government investigation was an aggravating factor in the court's decision to apply fraudulent concealment doctrine. Id. at 228. The Richards court held that the government officials" acts in the case before it constituted the same type of "affirmative acts" as had been perpetrated in Fitzgerald. However, while the secret nature of the actions in Fitzgerald conforms to the traditional model of the self-concealing tort, see supra text accompanying notes 2-6, the denial does not, see supra text accompanying note 17.

47. 588 F. Supp. 247 (D. Utah 1984).

48. Id. at 347 (footnote omitted). 
United States, ${ }^{49}$ a suit brought on behalf of the Japanese-Americans interned in American concentration camps during World War II, the court held that government concealment of the absence of military necessity for the camps from the public and the Supreme Court tolled the limitations period until "an authoritative statement by one of the political branches, purporting to review the evidence when taken as a whole, could rebut the presumption articulated in Korematsu."so

Although these cases may signal a move away from strict application of the arm's length standard, no court has done more than provide an incomplete and ad hoc response to problems with the standard. ${ }^{.12}$ The Hohri court went so far as to couple its holding with the caveat that the facts before it were "sui generis," and its decision was "not the occasion to establish a new rule to govern future cases." ${ }^{.62}$ Thus, although some courts have refused to allow the plaintiffs before them to go without relief, by failing to articulate a coherent standard they have left future plaintiffs confronting government cover-up without adequate protection.

\section{The Government as Trusted Defendant}

Citizen allegations of government concealment demand analysis under the trusted defendant standard. ${ }^{53}$ From the totality of its political and legal dealings with its citizens, government engenders a special respect from and gains power over many citizens that should be reflected in the tolling doctrine. Applying the trusted defendant standard to most governmentcitizen relationships would give courts a principled way to respond to the difficulties facing plaintiffs confronting government cover-up.

This Part will demonstrate that most government-citizen relationships include all the attributes that have prompted courts to apply the trusted defendant standard: trust, ${ }^{54}$ an imbalance of power, ${ }^{55}$ and the concealing party's monopoly over information relating to its wrongdoing. ${ }^{56}$ It will then discuss federal decisions recognizing that the relationship of trust between government and citizen imposes a special duty of honesty and dis-

49. 782 F.2d 227 (D.C. Cir. 1986).

50. Hohri, 782 F.2d at 251 . The court stopped short of imposing a full duty of disclosure, however, holding that Congress' creation of a commission to investigate the concentration camps rather than the commission's subsequent findings was sufficient to start the limitations period. Id. at 253.

51. Even when circuit court panels agree to toll the limitations period, they can not always agree why. See, e.g., Vest v. Bossard, 700 F.2d 600 (10th Cir. 1983) (three judge panel split three ways on why limitations should be tolled in suit alleging massive cover-up by local government officials).

52. Hohri, 782 F.2d at 249.

53. This Note does not argue that all citizens alleging government concealment should be analyzed under the trusted defendant standard, nor that the standard should be restricted exclusively to citizens. See infra note 104.

54. See supra note 25 .

55. See supra note 26.

56. See supra note 27. 
closure on government and its officials. It will conclude by explaining how the two courts that have considered and rejected the application of the trusted defendant standard to government-citizen relationships have misperceived the doctrine's scope and effect.

\section{A. Common Law Factors}

\section{Trust in Government}

While faith in government was eroded by Watergate and other scandals in the early Seventies, recent polls show a resurgence of trust in government $^{57}$ and in government officers. ${ }^{58}$ No poll, of course, can gauge the symbolic power of official action. ${ }^{58}$ The presumptive legality of government action affects a citizen's readiness to suspect the government of wrongdoing in a way that defies simple quantification. Citizens are deterred from bringing actions against the government by a complex and subtle interplay among the legal, psychological, and political factors that shape a citizen's perception of governmental authority. ${ }^{60}$ Even a jaundiced observer of government action can evince an enduring faith in government honesty and forthrightness. ${ }^{\text {B1 }}$

57. When posed the question, "[h]ow much of the time do you think you can trust the government in Washington to do what is right-just about always, most of the time, or only some time?," $53 \%$ of Americans in 1984 answered "most of the time," as opposed to 23\% in 1980, and 27\% in 1978. Center for Political Studies, American National Election Studies (1981-1985) (unpublished study) (on file with author). See also Glymer, Americans in Poll View Government More Confidently, N.Y.

Times, Nov. 19, 1984, at A1, col. 4 (reporting results of study). American citizens place far greater faith in government than do citizens of other Western democracies. See Dionne, Government Trust: Less in West Europe Than in U.S., N.Y. Times, Feb. 16, 1986, at 20, col. 1 (polls show that 49\% of Americans trust government in Washington to do what is right all or most of time, and only seven percent almost never trust it to do what is right, as opposed to far lower percentages in Western Europe.). See generally Dalton, Taking the Right to Appeal (More or Less) Seriously, 95 YALE L. J. 63, 95 n.111 (1985) (discussing personal nature of government-citizen relationship).

58. When asked the question, "[d]o you think that quite a few of the people running the government are a little crooked, not very many are, or do you think hardly any of them are crooked at all?," $64 \%$ of Americans in 1984 answered "not many" or "hardly any", as opposed to $49 \%$ in 1980 and $53 \%$ in 1978. Center for Political Studies, supra, note 57.

A recent Gallup poll designed to assess the "honesty and ethical standards" of various professions found that policemen ranked seventh of the twenty occupations tested. In response to the question, "[h]ow would you rate the honesty and ethical standards of [policemen]-very high, high, average, low, or very low?," $47 \%$ of the respondents answered high or very high, $41 \%$ said average, and only 10\% answered low or very low. San Francisco Chron., Aug. 16, 1985, at 30, col. 1.

59. See Bivens v. Six Unknown Agents of Federal Bureau of Narcotics, 403 U.S. 388, 391-95 (1971) (describing unique and extraordinary power of government officials).

60. See Allen v. United States, 588 F. Supp. 247, 343 (D. Utah 1984) (victim of government atomic testing believed that government would not conduct testing unless it knew it was safe); $H$. Ball, Justice Downwind: The Story of America's Atomic Testing Program 56 (1986) (describing how Utah citizens' patriotism and faith in government inhibited their discovery that government atomic testing injured them); U.S. COMMISSION ON WARTIME RELOcation AND INTERNment of Civilians, Personal Justice Denied 126 (1983) (social scientists believe that the Japanese-Americans interned in concentration camps were deterred from bringing legal claims by surprising super-patriotism they have labelled the "150\% American Syndrome").

61. As one federal judge remarked upon discovering that government attorneys had committed 


\section{An Imbalance of Power}

The imbalance of power between individual citizens and the government is obvious. ${ }^{62}$ The government's superior position in part springs from its clear advantage in resources. Much of the government's power, however, derives from its unique ability to coerce.

The expansion of the government's provisions of goods and services in the last two decades has given the government greater leverage over many citizens. ${ }^{63}$ A more dependent citizenry is more susceptible to government coercion and less apt to challenge government action.

Even among citizens who do not rely on government programs, the state's coercive power can greatly inhibit the accumulation of information. At times this coercive power arises from the legal prerogatives the government can bring to the litigation process. No other defendant, for example, can threaten potentially adverse informants or witnesses with prosecution. ${ }^{64}$ Particularly on the local level, the government can exert sufficient pressure to stifle the flow of information to an injured citizen. ${ }^{65}$

what he believed to be fraud upon his court in a trial over a quarter century earlier:

[I]t is quite true that judged by modern insights I took a somewhat pristine view at the original

trial of the general integrity of government officials . . . . I suppose that I shall continue to do

so, despite the buffetings of Watergate, these proceedings, and other current disclosures.

Bulloch v. United States, 95 F.R.D. 123, 143 (D. Utah 1982) (Christensen, J.) (government committed fraud on court in 1956 suit by concealing evidence relating to dangerousness of atomic testing), rev'd, 721 F.2d 713 (10th Cir. 1983), affd en banc, 763 F.2d 1115 (10th Cir. 1985), cert. denied 106 S. Ct. 862 (1986). Those less intimate with litigation in the federal courts are likely to retain an even greater continuing faith in government. See also Barrett v. United States, 689 F.2d 324, 326 (2d Cir. 1982) ("Today's average citizen would doubtless be appalled, but probably not surprised, to learn that in the early 1950's, while conducting a chemical warfare experiment, the United States Army used certain individuals as test subjects."), cert. denied sub nom. Cattell v. Barrett, 462 U.S. 1131 (1983).

62. This imbalance may be exaggerated in the concealment context. Those most apt to be the victims of official concealment may be those least able to discover their claims. As Judge Weinstein has observed:

[T] he law should take account of the fact that the people who bring these civil rights cases in the federal courts often proceed pro se, are ignorant of the niceties of state and federal practice, and lack the contacts with the legal profession that the more well-to-do and assured of our society rely on to prevent having claims barred by the statute of limitations.

Singleton v. City of New York, 632 F.2d 185, 196 (2d Cir. 1980) (Weinstein, J., dissenting), cert. denied, 450 U.S. 920 (1981).

63. The coercive power that attends government benefits can be great. See, e.g., Cox v. Stanton, 529 F.2d 47, 49 (4th. Cir. 1975) (teenage mother told that continued receipt of welfare funds was contingent on consent to reversible sterilization that turned out to be irreversible). See generally Reich, The New Property, 73 Yale L. J. 733 (1964) (discussing expansion of government programs).

64. See, e.g., Vest v. Bossard, 700 F.2d 600, 607 (10th Cir. 1983) (McKay, J., concurring) (local officials sent two teenagers to state correctional school for failing to comply with malicious prosecution, and threatened to prosecute a third for perjury if he recanted government fabricated accusation); Barrett v. United States, 689 F.2d 324, 328 (2d Cir. 1982) (government threatened to prosecute adverse witnesses under the Espionage Act in order to to cover up unauthorized chemical warfare testing), cert. denied sub nom. Cattell v. Barrett, 462 U.S. 1131 (1983).

65. In Vest v. Bossard, 700 F.2d 600 (10th Cir. 1983), for example, a judge, prosecutor, county attorney, and a probation officer wanted to force a local college professor out of town. First they forced a probationary teenager to accuse him of sodomy. When despite the threat of prosecution for 
Even if they suspect government officials of wrongdoing, citizens may be reluctant to make their suspicions known, fearing (sometimes quite reasonably) that challenges to official wrongdoing will lead to retribution. This is especially likely to be true on the local level, where the suspected wrongdoer and the authority with whom one registers complaints may be closely related if not one and the same. But even if the source of wrongdoing is a distant federal government, plaintiffs may forestall inquiry out of fear. ${ }^{68}$

\section{The Government Monopoly on Information}

The government's powers of coercion are supplemented by its ability to keep material information secret. Unlike most defendants, the government has legitimate justifications for secrecy that it can invoke for illegitimate purposes. Only the government can thwart a civil suit for damages by claiming it cannot disclose the identity of a witness because he is an informant, ${ }^{67}$ or avoid a court's subpoena by claiming that disclosure would endanger national security. ${ }^{88}$ State and local governments can make similar claims in connection with their police function. ${ }^{69}$

The difficulty of access to government information is compounded by the fact that the government is often the only source of information about events related to its wrongdoing. As a unique entity, often performing tasks without competitors with whom its activities can be compared or from whom information can be gleaned, the government has a special

perjury, the teenager recanted, the judge insisted that the accused professor plead guilty and spend six months in the Veterans Hospital. To insure that the professor could not talk to the recanter, the conspirators placed the teenager under police surveillance for five years. Id. at 607 (McKay, J., concurring).

66. To take an extreme but illustrative example, empirical evidence suggests that the JapaneseAmericans interned in concentration camps during World War II did not challenge the legitimacy of the government's actions until long after they were released because they feared that such a challenge would return them to captivity. S. Fukishima \& K. Ito, The Effects of Relocation on the Mental. Health of Japanese-Americans: Evaluation of the Literature and RecommenDAtions, (presented to the United States Commission on Wartime Relocation, Papers of the Commission, Part II 1983).

67. See Bergman v. United States, 565 F. Supp. 1353, 1358-61 (W.D. Mich. 1983) (discussing extent of privilege and citing cases).

68. See, e.g., Fitzgerald v. Seamans, 553 F.2d 220, 228 (D.C. Cir. 1977) (request for information); Barrett v. United States, 689 F.2d 324, 328 (2d Cir. 1982), cert. denied sub nom. Cattell v. Barrett, 462 U.S. 1131 (1983) (subpoena).

69. See Hobson v. Wilson, 737 F.2d 1, 41 (D.C. Cir. 1985) (local police claimed law enforcement considerations required them to keep information pertaining to alleged wrongdoing secret), cert. denied sub nom. Brennan v. Hobson, $105 \mathrm{~S}$. Ct. 1843 (1985); see also Bell v. Milwaukee, 746 F.2d 1205, 1216-22 (7th Cir. 1984) (discussing cover-up by Milwaukee police).

While the government's initial obligation to disclose under the Freedom of Information Act (FOIA), 5 U.S.C. $\$ 8552$ (1982), is certainly greater than the pre-discovery duties of a private litigant, once the government has reason to believe it has no disclosure obligations under the Act, it may be more bold than a private litigant in its refusals to disclose. State governments may follow a similar strategy under state analogs of FOIA. 
ability to suppress information completely. For example, for years the government was the only party capable of gathering and analyzing information about the danger of the radioactive fallout from the atomic testing it conducted over Nevada and the Marshall Islands. ${ }^{70}$ In both locations, the government was reluctant to test radiation levels; the tests it did conduct were incomplete, negligently prepared, or falsely interpreted. ${ }^{\mathbf{7 1}} \mathrm{Had}$ the government been a private party, the plaintiffs not only would have been more suspicious, but they also might have been able to seek assistance from public authorities. ${ }^{72}$

Finally, when information is technically available, even diligent plaintiffs may have difficulty obtaining it. Government information, particularly data amassed by the federal government, is often distributed throughout a vast bureaucracy, and available only to those who have the time, money and expertise to locate it. ${ }^{73}$ While at least one court has acknowledged that it "cannot impose an obligation on all citizens to initiate a triennial request of the Government" to determine whether their rights have been violated, ${ }^{74}$ another court suggested that the plaintiff's failure to

70. See Nitol v. United States, 7 Cl. Ct. 405, 410, 414 (1985) (discussing testing in Marshall Islands); Bulloch v. United States, 95 F.R.D. 123, 144 (D. Utah 1982), rev'd, 721 F.2d 713, affd en banc, 763 F.2d 1115 (10th Gir. 1985), cert. denied, 106 S. Ct. 862 (1986) (discussing testing in Nevada); H. BALL, supra note 60 , at 129-30, 197-98 (same).

The range of information over which the government wields a monopoly is not limited to the technologically esoteric. For example, until classified evidence became public, only the government could know whether the government believed there was a military necessity for the wartime relocation camps. See Hohri v. United States, 782 F.2d 227 (D.C. Cir. 1986) (tolling claim brought by Japanese-Americans interned in American concentration camps during World War II). See generally $P$. IRONS, JUSTICE AT WAR (1983) (discussing government cover-up of information about military necessity).

71. See cases cited supra note 70. See also Staff of House Subcomm. on Oversight and

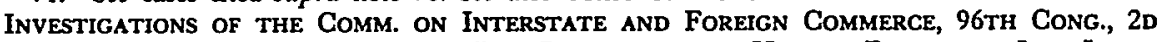
Sfss., "The Forgotten Guinea Pigs": A Report on the Health Effects of Low-Level Radiation Sustained as a Result of the Nuclear Weapons Testing Program Conducted by the United States Government 22 (Comm. Print 1980) [hereinafter cited as House SubCOMM. ON OVERSIGHT AND INVESTIGATIONS] ("the government falsely interpreted and reported radiation rates so as to give an inaccurate estimate of the hazards [and] knowingly disregarded evidence"); H. Bal.L, supra note 60, at 130, 197-98 (discussing Nevada testing).

72. The government's superior ability to conceal information is subject to two important qualifications. First, government activity is likely to be subject to greater media scrutiny than is the activity of a private party. Second, "government" is not monolithic. It is divided into at least three levels of authority-federal, state, and local-each of which are separated again into as many as three independent branches. Any of these governmental units might be able to assist a citizen concerned that a different governmental unit had concealed evidence of wrongdoing. That said, it should be noted that governmental units can use their superior ability to suppress information to keep data from the press or other governmental units. For example, the Atomic Energy Commission kept information about the danger of atomic testing in Nevada secret despite the efforts of local newspapers, local government officials, and high-level employees of the United States Department of Health, Education and Welfare (HEW). See H. BALL, supra note 60 at 67-83 (local newspapers); House SubCOMM. ON OVERSIGHT AND INVESTIGATIONS, supra note 71, at 6-7, 21 (state officials and HEW).

73. See Marcus, supra note 1, at 895-897 (discussing difficulty of obtaining government information).

74. Smith v. Nixon, 606 F.2d 1183, 1191 (D.C. Cir. 1979), cert. denied, 454 U.S. 912 (1981) 
submit an information request under federal and state freedom of information acts started the limitations period. ${ }^{75}$ One court rejected as an "aggravating factor" the fact that material government documents were dispersed in eighteen different archives in seven states. ${ }^{78}$

\section{B. The Government-Citizen Relationship in Federal Court}

\section{The Intangible Rights Doctrine}

Placing the government-citizen relationship within the trusted defendant standard would not require a radical recharacterization of the government-citizen relationship. Indeed, analyzing government concealment under the trusted defendant standard would comport with the Founder's vision of the proper relationship between government and citizen. The Lockean theory central to those who drafted the Constitution ${ }^{77}$ envisioned a government with a "fiduciary" duty to protect its citizens. ${ }^{78}$

While the Founders' conception of the government-citizen relationship has not been reflected consistently in the case law, ${ }^{78}$ their view is reflected in a line of criminal prosecutions strikingly analogous to the fraudulent concealment context. In those prosecutions, federal courts have held government and quasi-government officials to a fiduciary duty that includes the public's "intangible" right to the official's honest and faithful participation in government affairs. ${ }^{80}$ Under this doctrine, courts have imposed

75. Hauptmann v. Wilentz, 570 F. Supp. 351, 399 (D.N.J. 1983), affd, 770 F.2d 1070 (3d Cir. 1985).

76. Hohri v. United States, 586 F. Supp. 769, 791 (D.D.C. 1984), rev'd on other grounds, 782 F.2d 227 (D.C. Cir. 1986).

77. See G. Wood, The Creation of the American Republic: 1776-1787, at 283, 289-90, 601 (1969) (discussing Locke's influence).

78. See J. Locke, Second Treatise of Government § 156, at 88 (T.. Peardon ed. 1979) (1st. ed. London 1690) (executive's power is "fiduciary trust" which citizens have "placed in him for the safety of the people"); $i d$. $\S 149$, at 84 (government's legislative power is "fiduciary power" or "trust" citizens have reposed); id. $\S 171$, at 97 (people have "express or tacit trust" that power delegated to government "shall be employed for their good and the preservation of their property"); See also Peardon, Introduction to J. Locke, Second Treatise of Government, at xv (Locke believed government owed fiduciary duty or duty of trust to people); see also Hohri v. United States, 782 F.2d 227, 256 (D.C. Cir. 1986) (the Founders "most certainly assumed that the leaders of this Republic would act truthfully").

79. See Ackerman v. United States, 340 U.S. 193, 198 (1950) (no fiduciary relationship between government officer and naturalized citizen).

80. See, e.g., United States v. Margiotta, 688 F.2d 108, 120-23 (2d Cir. 1982) (quasi-public official violated mail fraud statute by taking private interest in public project and by failing to meet affirmative duty to disclose material information surrounding his activities), cert. denied, 461 U.S. 913 (1983); United States v. Mandel, 591 F.2d 1347, 1358 (4th Cir.) (governor violated mail fraud statute by failing to disclose material information surrounding his interest in public project, and offering deliberately misleading statement to public body), affd en banc in relevant part, $602 \mathrm{~F} .2 \mathrm{~d} 653$ (1979), cert. denied, 445 U.S. 961 (1980); United States v. Brown, 540 F.2d 364, 374 (8th Cir. 1976) (building commissioner's acceptance of kickbacks violated mail fraud statute by denying public's intangible right to honest and faithful service); of. Coffee, supra note 23, at 143 (criticizing above decisions for turning mail fraud statute into " "Truth-in-Government' Act"). 
upon a wide range of public officials a duty to disclose information about their wrongdoing, ${ }^{81}$ and have held that failure to disclose breaches the official's duty to the public. ${ }^{82}$ An official's concealment is actionable under the mail fraud statute ${ }^{83}$ and under the common law. ${ }^{84}$

These decisions amount to a criminalization of fraudulent concealment when committed to further individual rather than "official" wrongdoing. Indeed, the term "fraudulent concealment" has been used to describe these offenses. ${ }^{85}$ The holdings are animated by the belief that the government has a duty to be faithful to the trust that citizens have vested in it. As the Second Circuit noted:

Justice Holmes once wrote that "[m]en must turn square corners when they deal with the government." It requires little imaginative leap to conclude that individuals who in reality or effect are the government owe a fiduciary duty to the citizenry. ${ }^{86}$

It takes an equally small imaginative leap to recognize that this principle is as applicable in the tolling context as it is in criminal prosecutions. If a government officer's fraudulent concealment is sufficient to send him to jail, government concealment should be sufficient to stop the statute of limitations from running in a civil claim.

While no federal court has made this connection, the Supreme Court of Illinois has applied the intangible-rights rationale in the tolling context. In Chicago Park District v. Kenroy, Inc. ${ }^{87}$ the court applied the trusted defendant standard in a case brought by the City of Chicago against an alderman. The Court held that the alderman owed a fiduciary duty to the city, and held that his failure to disclose wrongdoing constituted fraudulent concealment, tolling the limitations period. ${ }^{88}$

81. See Margiotta, 688 F.2d at 142 (Winter, J., dissenting) (the courts have brought "virtually all participants in government and politics under the rubric fiduciary").

82. See, e.g., Mandel, 591 F.2d at 1363.

83. See cases cited supra note 80.

84. Mandel held:

a duty to disclose material information need not necessarily be based upon the existence of some statute or regulation prescribing such a duty. Rather, the duty to disclose may exist because of the relationship between the one possessing the material information and another .... So far as relevant in this case, the Governor of the State of Maryland is trustee for the citizens and the State of Maryland and thus owes the normal fiduciary duties of a trustee, e.g., honesty and loyalty.

591 F.2d at 1363.

85. Mandel, 591 F.2d at 1355.

86. Margiotta, 688 F.2d at 124 (citations omitted).

87. 78 Ill. 2 d 555,402 N.E.2d 181 (1980).

88. Id. at 563,402 N.E.2d at 185 ("To hold that the City was obligated to search for the misfeasance of its duly elected public official, absent a prior indication of wrongdoing, would require it to presume unfaithfulness on the part of its fiduciary."). 


\section{Government Cover-up}

\section{The Trusted Defendant Standard in Federal Court}

The two federal courts that have considered the argument that the trusted defendant standard should be applied to government-citizen relationships both refused to depart from the arm's length standard. ${ }^{89}$ Neither court, however, appears to have understood the range of relationships to which the trusted defendant standard applies. The courts did not apply the factors generally used to determine the tolling standard..$^{90}$ Instead, both courts apparently assumed that the trusted defendant standard applies only to strict fiduciary relationships ${ }^{91}$ and based their holdings on the grounds that the government is not the citizen's fiduciary. ${ }^{92}$

In both instances, the refusal to adopt the trusted defendant standard seems animated by an unfounded fear that to do so would expose the government to an expansive range of new duties and liabilities. ${ }^{93}$ Both

89. Hohri v. United States, 586 F. Supp. 769, 791-93 (D.D.C 1984), rev'd on other grounds, 782 F.2d 227 (D.C. Cir. 1986); Barrett v. Hoffman, 521 F. Supp. 307, 315 (S.D.N.Y. 1981), rev'd on other grounds sub nom. Barrett v. United States, 689 F.2d 324 (2d Cir. 1982), cert. denied sub nom. Cattel v. Barrett, 462 U.S. 1131 (1983). The Barrett holding was complicated, however, by the fact that the court considered the duties that emanate from the government-citizen relationship in conjunction with plaintiff's argument that those duties also emanate from the due process clause. Id. at 314-15; see infra note 97 (discussing Barrett due process analysis).

Only in cases brought by Native Americans, to whom the government has a fiduciary duty imposed by statute, have the courts wavered in their application of the arm's length standard. See, e.g., Manchester Band of Pomo Indians, Inc. v. United States, 363 F. Supp. 1238, 1249 (N.D. Cal. 1973) (tolling statute of limitations).

90. See supra text accompanying notes $26-28$.

91. Hohri, 586 F. Supp. at 791; Barrett, 521 F. Supp. at 315. The Hohri court showed its lack of understanding of the types of relationships subsumed under the trusted defendant standard by addressing the question of whether the government-citizen relationship affected the tolling decision in its discussion of whether the government was liable for damages caused by an alleged breach of fiduciary duty. 586 F. Supp. at 792-93.

92. Hohri, 586 F. Supp. at 791-93; Barrett, 521 F. Supp. at 315; see also Smith v. Nixon, 606 F.2d 1183, 1190 (D.C. Cir. 1979) (commenting in dictum that no "formal" fiduciary relationship existed between parties in Fitzgerald v. Seamans, 553 F.2d 220 (D.C. Cir. 1977), a middle level Department of Defense employee and a White House official), cert. denied, 453 U.S. 912 (1981).

As additional support for its decision, the Barrett court cited its finding that the government is subject to the same discovery rules and civil sanctions as any other litigant in the federal courts. 521 F. Supp. at 315. As a basis for refusing to apply the trusted defendant standard this reasoning is flawed for two reasons. First, the validity of the statement itself is undermined by the very case relied upon by Barrett to support it: NAACP, Western Region v. Hodgson, 57 F.R.D. 81 (D.D.C. 1972). That case recognized the specialness of the government in its holding that the "paramount interests of the Government in having justice done between litigants in the federal courts militates in favor of requiring great effort on its part to produce any documents relevant to a fair determination of this litigation." Id. at 83 (quoting Freeman v. Seligson, 405 F.2d 1326, 1337-38 (D.C. Cir. 1968)).

Second, the court's reliance on discovery doctrine confuses the tolling decision's concern with events before suit is filed with the rules governing actions after a suit is filed. Discovery doctrine is not relevant to whether the trusted defendant standard is applicable. See supra text accompanying notes 25-26.

93. The Hohri court considered the tolling argument in the context of a damages claim for breach of fiduciary duty. See supra note 91 . The Barrett court considered the tolling argument in the context of plaintiff's claim that the government had a constitutional obligation to disclose its wrongdoing, see infra note 97, and that the cover-up should give rise to a cause of action for damages under the Fifth Amendment. Barrett, 521 F. Supp. at 315. 
courts' rigid reliance on the arm's length standard resulted in reversal on appeal, where the circuit courts, without addressing the question of which tolling standard should be applied, found ways nominally under the arm's length standard to reverse the trial courts' holdings. ${ }^{94}$

\section{Constitutional Rights Threatened by Government CONCEALMENT}

An important additional reason to analyze government cover-up under the trusted defendant standard is that in many instances use of the arm's length standard will deprive a litigant of his constitutionally protected right of access to court. In Logan v. Zimmerman Brush Co. ${ }^{95}$ the Supreme Court held that a cause of action is a species of property under the due process clause. ${ }^{98}$ Under the Logan analysis, government cover-up, by depriving a citizen of his property interest in his cause of action, may abridge his procedural right of access to court. ${ }^{97}$

94. Hohri v. United States, 782 F.2d 227, 253 (D.C. Cir. 1986) (tolling limitations period under arm's length doctrine); Barrett v. United States, 689 F.2d 324, 330, 333 (2d Cir. 1982) (reversing summary judgment in favor of government under arm's length doctrine and due process analysis), cert. denied sub. nom. Cattell v. Barrett, 462 U.S. 1131 (1983). For a discussion of courts' tendency to keep claims alive by making ad hoc alterations in the arm's length doctrine, see supra text accompanying notes 44-52. For a discussion of the Barrett court's due process analysis, see infra note 97.

95. 455 U.S. 422 (1982) (Illinois procedure barring suit under state antidiscrimination statute within limitations period violated constitutional right to due process).

96. Id. at 428.

97. The procedural due process argument suggested here is similar to that set forth in Note, The Fairness and Constitutionality of Statutes of Limitations for Toxic Tort Suits, 96 Harv. L. REv. $1683,1692-95$ (1983) (statutes of repose governing toxic tort suits deprive plaintiffs of constitutional right of access to court absent legislative quid pro quo).

Two additional constitutional theories support application of the trusted defendant standard to the government. Both arguments proceed from the court's holding in Logan that a plaintiff has a constitutionally significant property right in his cause of action. From this premise the first argument asserts that government cover-up implicates constitutional rights in a way that concealment by other parties does not. It concludes that the importance of safeguarding constitutional rights and applying uniform constitutional standards, see Bivens v. Six Unknown Named Agents of the Federal Bureau of Narcotics, 403 U.S. 388, 409 (1971) (Harlan, J., concurring), mandates that courts employ the trusted defendant standard because it is the only standard that accurately and consistently reflects the difficulties a plaintiff confronts when faced with government concealment. See supra text accompanying notes 53-76.

The second alternative is that government cover-up constitutes a deprivation of substantive due process. This argument also can be based on Logan, which some commentators characterize as a substantive due process case masquerading as a case about procedural rights. See, e.g., The Supreme Court, 1981 Term, 96 HARv. L. Rev. 62, 102-105 (1982). According to this line of reasoning, just as Logan found that Illinois had taken Logan's constitutionally imbued property right by depriving him of his right to sue under the state's antidiscrimination statute, so the government deprives a citizen of his constitutional property right when it conceals his cause of action. This theory apparently informed the decision in Barrett v. United States, 689 F.2d 324 (2d Cir. 1982), cert. denied sub nom. Cattell v. Barrett, 462 U.S. 1131 (1983), where the court held that plaintiffs could bring an action under $\S 1983$ to recover the difference between the money they had received in a settlement and the moncy they would have recovered had government concealment not inhibited their ability to take full advantage of the legal claims available to them. Id. at 331-33. The court's cursory treatment of this issue, however, left the rationale and implications of its decision unclear. The major flaw in the substantive due process argument is that it knows no bounds: It implies that each instance of govern- 
As the Logan court explained, the constitutional right of access to court is premised on the principle that, "having made access to court an entitlement or a necessity, the State may not deprive someone of that access unless the balance of state and private interests favors the governmental scheme." ${ }^{08}$ More specifically, the Gourt has held that a constitutional right of access to court exists where, "absent a countervailing interest of overriding significance," a plaintiff seeks to vindicate a fundamental right and the court is the only forum in which that right can be vindicated. ${ }^{90}$

In the fraudulent concealment context, a constitutional right of access could be asserted by a plaintiff who seeks to vindicate his fundamental interest in personal security and bodily integrity ${ }^{100}$ jeopardized by a concealed government tort where redress outside the courtroom is unavailable. ${ }^{101}$ When government action threatens that fundamental interest and the government can prove no overriding state interest, a constitutional right of access should protect plaintiff's cause of action.

Logan and the access to court cases do not establish an exact formula for deciding how the test balancing competing governmental and private interests should be calculated. When a plaintiff alleges government concealment, however, tolling doctrine itself provides the proper test. Constitutional issues aside, the tolling decision always involves balancing competing interests: The citizen's interest in holding the government

ment cover-up would toll the statute of limitations, regardless of the identity of the plaintiff or the character of the plaintiffs relationship with the government.

98. Logan, 455 U.S. 430 n.5.

99. Id. (quoting Boddie v. Connecticut, 401 U.S. 371, 377 (1971)). In Boddie, the court held that a class of indigent women seeking to waive court fees in order to obtain divorces had a constitutional right of access to court. The Boddie holding subsequently was clarified by United States v. Kras, 409 U.S. 434 (1973), in which the court held that in order to assert a constitutional right of access to court a plaintiff must seek to vindicate a fundamental interest, and the state must have exclusive control over the "adjustment of [the] legal relationship." Id. at 445. In Logan, the access to court cases were presented as an "analogous method of analysis" in support of the Court's decision declaring unconstitutional the Illinois procedure that denied plaintiff his right to bring suit under a state antidiscrimination statute. Logan, 455 U.S. at 430 n.5.

100. See Ingraham v. Wright, 430 U.S. 651, 673 (1977) ("Among the historic liberties . . . protected [by the Due Process Clause] was a right to be free from, and to obtain judicial relief for, unjustified intrusions on personal security."); see also id. at nn.41-42; Note, supra note 97, at 1693 (fundamental interest in personal security and bodily integrity threatened by statutes of repose for toxic tort suits).

101. Few prospective litigants are able to secure a remedy outside the courtroom. Without a valid remedy in court, an individual has no leverage with which to negotiate a private settlement. The only remaining non-judicial forum in which the prospective litigant might secure relief is the legislature. It is enormously difficult, however, to secure legislative relief for a specific injury sustained as a result of government action. Even the citizens injured by government atomic testing in the 1950 's, whose injuries have been well-publicized, confirmed by a congressional report, and championed by state and federal elected officials, have been unable to secure relief from Congress. H. BALt., supra note 60 , at 130-32, 177 (discussing failed legislative attempts). Legislators "are wary of having a compensation program turn into a continuing, disruptive, draining entitlement program for other groups in the society who have also been injured and wrongfully killed due to government negligence." Id. at 177 . 
responsible for its wrongdoing is weighed against the government's interest in being free of stale claims. ${ }^{102}$ The citizen's constitutional right of access to court requires an adjustment in how the balance is struck. In a case involving government concealment, the trusted defendant standard provides the adjustment needed to take account of that constitutional dimension. To apply the arm's length test-in other words, not to adjust the tolling standard-would ignore the constitutional issue. The balance struck by the trusted defendant standard comports with the directive of the constitutional test that "absent a countervailing interest of overriding significance,"103 a citizen should have access to a judicial forum in which to assert his property right. In short, the trusted defendant standard test satisfies the due process clause as well as traditional tolling principles.

\section{Emploxing the Trusted Defendant Standard}

\section{A. The Trusted Defendant Standard in Practice}

Courts should account for the special relationship between government and citizen and the citizen's right of access to court when assessing claims of government cover-up. Accordingly, in the absence of evidence showing that a plaintiff deals with the government at arm's length, ${ }^{104}$ courts should apply the trusted defendant standard when assessing claims by citizens alleging government cover-up. ${ }^{105}$ The government should be under a duty

102. See supra text accompanying notes 1-11.

103. Logan, 455 U.S. at 430 n.5 (citation omitted) (stating test).

104. The trusted defendant standard should not automatically apply to all citizens alleging government concealment, nor should it be restricted to citizens. The standard has always found categorizations useful, but not dispositive. See supra notes 28-29 and accompanying text. It is likely, however, that the standard would apply to most government-citizen relationships, and would not apply to suits not brought by individual citizens. The standard would be entirely inappropriate, for example, in the context of commercial relations between a large corporation and the government. Corporations and other large organizations simply do not have a relationship with government which inspires the kind of trust required for application of the trusted defendant standard. In addition, while few organizations can match the resources of the federal government, most organizations will not suffer from the same debilitating disadvantages that face a citizen trying to uncover government wrongdoing.

Among private citizens, too, the difficulty of uncovering government information will differ. Unlike the government-business relationship, however, it should be presumed that the citizen's relationship with the government places him at a grave disadvantage. For citizens for whom this is clearly not true, the doctrine affords sufficient flexibility to deny application of the trusted defendant standard. See supra text accompanying note 29 (discussing standard's flexibility).

While this distinction between citizens and corporations cannot be exact, in general it is consonant with a presumption that parties who deal on a commercial basis are subject to a more exacting tolling standard. See Developments, supra note 20 , at 1217 (there is "an even stronger policy against requiring the suspicious attitude of diligence exacted of persons dealing on a commercial basis").

105. For a more elaborate discussion of the theory and mechanics of the trusted defendant standard, see supra text accompanying notes 18-29. Another possible substitute for the arm's length doctrine is the doctrine of estoppel. One federal court has held that the government's concealment estops it from raising a limitations defense. Bell v. City of Milwaukee, 746 F.2d 1205, 1231 (7th Cir. 1984) (applying Wisconsin law). Unlike the equitable tolling proposed in this Note, however, estoppel does not provide a broadly applicable solution to the problem of government concealment. Estoppel is less 


\section{Government Cover-up}

to disclose its wrongdoing. ${ }^{106}$ Its failure to disclose wrongdoing, or its false denial of wrongdoing, should constitute fraudulent concealment, tolling the statute of limitations. The limitations period should remain tolled until the plaintiff discovers, or should have discovered, the concealed cause of action. ${ }^{107}$ In the determination of when the citizen should have discovered

likely to find general approval, and would only apply to a limited spectrum of government concealment on a deliberately ad hoc basis.

While courts will toll actions against the government, see note 31 (citing cases), as a general principle courts are extremely reluctant to estop the government. See 2 K. Davis, AdMinistrative Law TREATISE $\S 17.01$, at 491-92 (1958) ("courts usually hold that the doctrine of equitable estoppel does not apply to the government"); Note, Equitable Estoppel of the Government, 79 CoLuM. L. REv. 551, 551 (1979) ("[t]raditionally, courts have not permitted estoppel of the government, no matter how compelling the circumstances"); see also Heckler v. Community Health Services, 467 U.S. 51,60 (1984) (Court is "hesitant . . . to say there are no cases" in which estoppel of government would be appropriate) (emphasis omitted). The hostility to estoppel of government is based in large part on tradition. K. DAvis, supra, $\S 17.01$, at 491 . In addition, it has been argued that the general public should not suffer for the misrepresentations or mistakes of its agents, and that estoppel of government, by rendering the government incapable of enforcing the law, would undermine obedience to the rule of law. See Community Health Services, 467 U.S. at 60; see also Note, supra, at 565-67 (possible separation of powers problems involved in estoppel of government).

Another important advantage to the tolling approach is that whereas the doctrine of estoppel cannot be used to assert a limitations defense in a suit under the Federal Tort Claims Act, tolling is proper. See, e.g., Hohri v. United States, 586 F. Supp. 769, 786 n.22 (D.D.C. 1985), rev'd on other grounds, 782 F.2d 227 (D.C. Cir. 1986); Barrett v. Hoffman, 521 F. Supp. 307, 320 (S.D.N.Y. 1981), rev'd on other grounds sub nom. Barrett v. United States, 689 F.2d 324 (2d Cir. 1982), cert. denied sub nom. Cattell v. Barrett, 462 U.S. 1131 (1983). This is because the limitations period that governs the FTCA claim requirement is jurisdictional, and parties cannot create jurisdiction by their actions. Hohri, 586 F. Supp. at 786 n. 22; Barrett, 521 F. Supp. at 320 n. 17.

Finally, estoppel would only bar the government from asserting a limitations defense when it affirmatively denied or misrepresented its role in any wrongdoing. See Community Health Services, 467 U.S. at 59. The tolling approach advocated here also would apply to "self-concealing" torts. See supra text accompanying notes 2-6. In addition, it would impose on government a duty of disclosure. See infra text accompanying note 106.

106. See supra text accompanying note 20. It is important to emphasize that disclosure is not an admission of liability; it simply provides the plaintiff with full information about government activities in which he may have a direct interest. Obviously, if the government is intent on concealing information, or if it feels that the costs of disclosure are too great, then the duty to disclose will become a constructive duty, and will serve the purpose of tolling the limitations until a plaintiff knows or should have known of any claim.

The nature of the wrongdoing and the number of citizens potentially at risk will affect the requirements of notice. See Mullane v. Central Hanover Bank \& Trust Co., 339 U.S. 306, 314-45 (1950); Spevack v. United States, 390 F.2d 977, 982-84 (Ct. Cl. 1968) (government had not put scientist on notice of expropriation of his formula simply by declassifying evidence that they had used it, and could only provide proper notice by making a public announcement reasonably calculated to get his attention). The standard established by Spevack should govern the government's disclosure duties, though it would be disingenuous to suggest that any standard of disclosure can do more than give courts a guide to decisions that will turn on the particularized facts of individual cases.

107. The burden of proving due diligence has traditionally remained with the plaintiff, as the party seeking to toll the limitations period. See, e.g., Ramsey v. Culpepper, 738 F.2d 1092, 1098 (10th Cir. 1984); see also Gibson v. United States, 781 F.2d 1334, 1345 (9th Cir. 1986) (dismissing allegation of fraudulent concealment in part because plaintiff failed to allege due diligence). But see Hobson v. Wilson, 737 F.2d 1, 35 (D.C. Cir. 1984) (defendant has the burden of proving absence of due diligence in the D.C. Circuit), cert. denied sub nom. Brennan v. Hobson, 105 S. Ct. 1843 (1985). For this reason, and because the plaintiff is the party best able to bring evidence of his diligence before the court, this Note advocates leaving the burden of proof with the plaintiff. The difficulties facing a plaintiff confronting government concealment are better addressed through the less rigorous standard of diligence required by the trusted defendant tolling standard. 
the government's malfeasance, the citizen should be under no duty to mistrust the government, or suspect it of wrongdoing. Finally, the application of the trusted defendant standard should not alter the legal relationship between government and citizen in any other way. Aside from determining when the limitations period begins to run, the trusted defendant standard should not impose on government any new duties, obligations, or liabilities. ${ }^{108}$

\section{B. Achieving Larger Goals}

Applying the trusted defendant standard to citizen-government relationships will not only more accurately assess when the limitations period should run on a citizen's suit, but will serve larger social purposes as well. On a practical level, by increasing the likelihood that the government and its officers will be held accountable for their torts, application of the standard will deter government wrongdoing, help compensate victims of government cover-up, and spread the loss of any harm incurred.

More important, by compelling government disclosure and ceasing to penalize citizens for their trust in government, the standard would strengthen the relationship between government and citizen and foster greater faith in government honesty and forthrightness. The law would not only reflect the trust citizens place in government, but would encourage that trust. ${ }^{109}$

Finally, holding government accountable for its wrongdoings preserves the moral basis of the rule of law. ${ }^{110}$ As Justice Brandeis wrote:

Our Government is the potent, the omnipresent teacher. For good or for ill, it teaches the whole people by its example. . . . If the Gov-

The government, however, should have the burden of going forward with evidence that it has disclosed information sufficient to put a plaintiff on notice of his claim; the government is clearly the party best able to bring this evidence before the court. See, e.g., Smith v. Nixon, 606 F.2d 1183, 1191 (D.C. Cir. 1979), cert. denied, 453 U.S. 912 (1981).

108. Under the proposed change, the statute of limitations would remain "a defense separate from the denial of breach of duty." United States v. Kubrick, 444 U.S. 111, 125 (1979).

109. As Professor Dalton has written:

At its best, the connection between the people and their government is rather like a personal relationship. It is built on mutual need, mutual trust, give and take, shared responsibilities, and an irrational element that looks a lot like love. It is that relationship more than (or over and above) fear of punishment that makes people law-abiding, loyal, patriotic, and optimistic. I am convinced that the relationship is deepened whenever a government takes the people into its confidence, levels with them, and trusts them to make hard choices. Certainly the converse is true, as both Viet Nam and Watergate vividly demonstrate.

Dalton, supra note 57, at 95 n.111.

110. P. Schuck, Suing Government: Grtizen Remedies for Official Wrongs 23 (1983) (discussing benefits of holding government liable for its torts). 


\section{Government Cover-up}

ernment becomes a lawbreaker, it breeds contempt for law; it invites every man to become a law unto himself; it invites anarchy. ${ }^{111}$

When application of the arm's length standard allows the government to plead the statute of limitations successfully, the government's legal victory is society's loss. ${ }^{112}$

\section{Conclusion}

The citizen's trust in government and the government's ability to.conceal information create difficulties for the citizen that are not accounted for in the arm's length tolling standard federal courts presently apply to citizen allegations of government concealment. Analyzing citizen allegations of government concealment under the trusted defendant standard will enable those courts that have been sensitive to the unique characteristics of government concealment to ground their tolling decisions in an established legal doctrine in a manner that will provide guidance for future courts and remedies for future plaintiffs. It will also make those courts previously strict in the application of concealment doctrine, or blind to the peculiar factors involved in government cover-up, take notice of the diffculties facing a plaintiff seeking to uncover government-held and concealed information. The law should not only reflect citizen trust in government, but should encourage that trust by fostering government honesty and forthrightness.

111. Olmstead v. United States, 277 U.S. 438, 485 (1928) (Brandeis, J., dissenting).

112. Judge Jenkins, who presided over Allen v. United States, 588 F. Supp 247 (D. Utah 1984), in which the statute of limitations was tolled because government concealment prevented discovery of injuries suffered as a result of government atomic testing, has expressed a similar idea. In cases like Allen, he said, the question is never will the government "win or lose. The government always wins when justice is done . . . ." See Jenkins, Remarks Before Joint Meeting, 10 UTAH B. J. 1, 4 (1982). 